\title{
Research Notes
}

\section{APPLICATION OF A METHOD OF JOINT ANALYSIS OF FIELD DATA}

F. Pimentel Gomes ${ }^{2}$ developed a method of joint analysis of experiments in complete randomized blocks extended to include cases in which the number of replicates, as well as the number of regular treatments, varies from one experiment to another. This method was used to analyze the Gurabo and Naranjito experiments described below, because the adaptability of the varieties to a more extensive area may be accomplished more effectively by a joint analysis than when the data of the individual experiments are analyzed separately.

A. Acosta Matienzo and J. Vélez Santiago ${ }^{3}$ conducted variety trials with Xanthosoma at Gurabo, Naranjito, and Corozal. In each experiment 12 varieties were tested. Some of the varieties were common for all the experiments and some were tried only in the individual experiments. In all, 15 varieties were tested.

The experiments employed a $3 \times 4$ triple rectangular lattice design. The plots were 15 feet by 20 feet with 5 rows of 10 plants each, planted 3 feet apart between rows and 2 feet apart within the row. A 12-6-16 fertilizer was applied in two portions, 2 ounces per plant in the hole at planting time and 2 ounces 2 months later. Cultivation followed accepted practices.

The results were analyzed and significant differences were found at the 5-percent level of probability, using Tukey's test, between high-yielding and low-yielding varieties in the Gurabo and Naranjito experiments. The varieties Blanca, Rascana, Viequera and Drearies were considered among the highest producers because of their consistently good performance in the individual experiments.

The three variety trials were calculated as randomized blocks. The $F$ values of the Gurabo and Naranjito experiments were significant at the 1-percent level of probability while the $F$ value at the Corozal experiment was not significant as found previously by Acosta Matienzo and Vélez Santiago. ${ }^{4}$ The $F$ value for the treatments in the joint analysis was found to be significant at the 1-percent level of probability.

The joint analysis of Gurabo and Naranjito gave the following results:

1 Manuscript submitted to Editorial Board November 16, 1971.

2 Pimentel Gomes, F., An extension of the method of joint analysis of experiments in complete randomized blocks, Biometrics 26(2): 332-6, 1970.

${ }^{3}$ Acosta Matienzo, A., and Vélez Santiago, J., Yield trials with Xanthosoma varieties, J. Agr. Univ. P.R. 54(3): 562-9, 1970.

Ibid. 


\begin{tabular}{|c|c|c|c|c|c|}
\hline Source of variation & & D.F. & S.S. & M.S. & $F$ \\
\hline Experiments & $g-1$ & 1 & 60.96 & & \\
\hline Blocks within experiments & $\Sigma r_{i}-g$ & 4 & 2508.71 & & \\
\hline $\begin{array}{l}\text { Interaction: (common } \\
\text { treatments } \mathrm{X} \text { experi- } \\
\text { ments) }\end{array}$ & $(C-1)(g-1)$ & 7 & 2512.13 & 358.88 & 1.16 \\
\hline Treatments (adjusted) & $\Sigma Z_{i}+C-1$ & 15 & 36281.14 & 2418.74 & $7.81^{* *}$ \\
\hline Residual & By subtraction & 44 & 13615.33 & 309.44 & \\
\hline Total & $\sum r_{i}\left(Z_{i}+C\right)-1$ & 71 & 54978.27 & & \\
\hline
\end{tabular}

$g=$ number of experiments in complete randomized blocks

$r_{i}=$ number of replicates

$C=$ number of common varieties

$Z_{i}=$ number of regular varieties

** Significant of the 1-percent level of probability.

TaBLe 1.-Yields per cuerda' in the joint analysis

\begin{tabular}{rlrl}
\hline Rank & \multicolumn{1}{c}{ Variety } & $\begin{array}{c}\text { Hundred- } \\
\text { weights }\end{array}$ & \multicolumn{1}{c}{ Significant differences over- } \\
\hline 1 & Rascana & 116.69 & $12^{*}, 13^{*}, 14^{* *}, 15^{* *}, 16^{* *}$ \\
2 & Viequera & 115.88 & $12^{*}, 14^{*}, 15^{* *}, 16^{* *}$ \\
3 & Drearies & 112.34 & $14^{*}, 15^{* *}, 16^{* *}$ \\
4 & Bisley & 110.94 & $14^{* *}, 15^{* *}, 16^{* *}$ \\
5 & Blanca & 110.81 & $14^{*}, 15^{*}, 16^{*}$ \\
6 & Rascana 2 & 110.11 & $14^{* *}, 15^{*}, 16^{*}$ \\
7 & Choubutton & 99.64 & $15^{*}, 16^{*}$ \\
8 & Barbados & 89.07 & $15^{*}, 16^{*}$ \\
9 & Charanelle & 86.73 & \\
10 & Vinola & 78.51 & \\
11 & Inglesa & 74.73 & \\
12 & Kelly & 63.18 & \\
13 & Blanca del Pais & 51.46 & \\
14 & Dominicana & 42.77 & \\
16 & Martinica & 8.09 & \\
16 & Martinica Amarilla & 7.98 & \\
\hline
\end{tabular}

1 A cuerda is equivalent to 0.9712 acres.

*-Significant differences at 5-percent level of probability.

**-Significant differences at 1-percent level of probability.

The varieties common at both experiments were Viequera, Bisley, Rascana, Blanca, Rascana 2, Kelly, Vinola, and Dominicana. The regular varieties at Gurabo (not included in Naranjito) were: Inglesa, Blanca del Pais, Martinica Amarilla, and Martinica. At Naranjito the regular varieties

- Rascana 2 consisted of material obtained from a commercial source and included originally under adifferent varietal name. 
(not included in Gurabo) were: Drearies, Choubutton, Barbados, and Charanelle.

Least significant differences were obtained for the different comparisons using Tukey's test at the 5- and 1-percent level of probability.

The comparisons are of four types: 1 , Differences between two regular variety means in the same experiment; 2 , differences between two regular variety means in different experiments; 3 , differences between two common variety means; 4 , difference between a common and a regular variety mean.

The results are given in table 1. Varieties Rascana, Viequera, Drearies, Bisley, and Blanca were found to produce the highest yields. Varieties Kelly, Blanca del País, Dominicana, Martinica, and Martinica Amarilla were found to produce least.

\author{
F. Mariota Trias \\ Agricultural Experiment Station, \\ Rio Piedras, and Faculty of \\ Agriculture \\ A. Acosta Matienzo \\ Gurabo Substation \\ Agricultural Experiment Station \\ J. Vélez Santiago \\ Corozal Substation \\ Agricultural Experiment Station
}

